\title{
The Preamble of 1945 Constitutions as Post-Colonial Normative Expression and Its Contextuality (A Politics of Law Analysis)
}

\author{
Arasy Pradana A Azis \\ Postgraduate Program, Faculty of Law, University of Indonesia \\ e-mail: arasyaziz@gmail.com
}

\begin{abstract}
The proclamation of Indonesian independence on August 17, 1945, marked Indonesia's transition from being a nation as an imaginary community to be a state as a legal-rational community. For the first time, the Indonesian has the authority to form the rule of law independently, apart from the intervention of the colonial nation. The fierce spirit of anti-colonialism was immediately reflected in various legislative products, including the 1945 Constitution. The opening part of the 1945 Constitution, which is often regarded as the highest source of value in the Indonesian legal system, reflects a thick post-colonial spirit. During the colonial period, the legal system was built on hegemony, by placing indigenous people as The Other in their own homeland. They are labeled as third-class identities, under other national groups. This mentality is then tried to be reversed after independence. The values of independence, perpetual peace, and social justice are presented clearly into the Preamble of the 1945 Constitution. The Preamble of the 1945 Constitution inherited the anticolonial spirit and immediately became a manifesto of resistance to colonial domination. However, the process of value petrifaction of the Preamble of the 1945 Constitution should not be considered as complete when that text was announced. The real challenge actually happened today, decades after Indonesia's independence. The injustice and hegemony relation that still occurs throughout the world ideally awakens the Indonesian to continue to contextualize anti-colonial values in the Preamble of the 1945 Constitution.
\end{abstract}

\section{Keywords}

The preamble of 1945 Constitutions, Post-Colonial, Politics of Law, Hegemony

Citation: Aziz, A.P.A. : The Preamble of 1945 Constitutions as Post-Colonial Normative Expression and Its Contextuality. In. D. Ekawati, et al (eds.): Proceeding of The American Studies International Conference 2018, Vol. 2, pp. 15-22 UGM Digital Press Social Sciences and Humanities (2019).

Published: May, 2019

\section{Introduction}

Hundreds of years ago, human societies that inhabited various corners of the Nusantara had once been one of the known powers in the world. Indonesian human ancestors with outrigger boats were noted to have crossed 70 kilometers of the ocean to find the Australia continent (Latif, 2015, p. 129). Furthermore, seafarers with very simple shipping technology even managed to reach new lands far off the west coast of the archipelago. The tip of their outrigger boats managed to touch 
Africa and Madagascar, ahead of any other nations (Latif, 2015, p. 130). The fleet of Indonesian ancestors developed increasingly complex and advanced, thus successfully building two giant maritime empires; Sriwijaya and Majapahit. Their territory stretched from peninsular Malaysia to the Philippines. The memory of their triumph was one of the important catalysts for the discourse of Indonesian national identity later (Kahin, 1959, p. 37).

However, the glory of history was hampered at the moment the foreign nations arrived at the archipelago. A period called Arus Balik (Backflow) in Yudi Latif's review. At first, people from India, Arabia, and China came to trade. Their presence was immediately followed by the landing of the Portuguese in the 16 th century (Latif, 2015, p. 135). The entire European mission was at the very core summarized in the slogan Gold, Glory, Gospel. The Portuguese were soon replaced by the Dutch under the fleet led by Cornelis de Houtman (Latif, 2015). This passage of history is often simplified as a period of colonialism.

Conceptually, colonialism did not merely manifest in the practice of taking tribute, property, and wealth from conquered territory. In addition, colonialism also changed the economic order and placed the indigenous people in complex relations with the parent countries, marked by the flow of people and resources migration from the colonies (Ania Loomba, 2016, p. 4-6). During the colonialism period, people of Nusantara had a new identity as citizens of the Dutch East Indies. The Inlander is placed as a subordinate of the European nation that controls the superstructure. Discriminatory politics is also reflected in the product of colonial law which also has a discriminatory character, like in the citizenship law. Article 163 of the Indische Staatsregeling (IS) composed Dutch Indies citizenship in a hierarchical structure. Europeans occupied the highest place, then foreigners as second-class citizens, and Indigenous people at the lowest place (Paulus, 1979, p. 74), Different categories of private law applied to each class.

The narrative above showed a historical narrative for political development that begins in the birth of a new nation called Indonesia. Indonesia had gone through a period where pockets of power were spread throughout the country. Each unit was independent and possessed sovereignty over itself. The entry of colonial power then made radical changes to this established order. With new state directions, the invaders restructured legal practices in society, from the paradigmatic level to positive law. Indirectly, there was a disruption of the legal culture of the archipelago from its original social values.

The momentum of independence than allowed the Indonesians to be free from the shackles of colonialism through the formation of their own legal order (Hamidi, 2006, p. 168); a legal system that was not only excavated from the soul of the Indonesians but also free from discrimination and exclusion of certain groups, a legal order that became the antithesis of the colonial legal system. Indonesia's proclamation drew a line between colonialism and Indonesia's new face, which many experts called the post-colonial period.

The "post-colonial" terminology can be used to signify two contexts. The post-colonial concept in the first context described a momentum when colonialism was successfully removed from Indonesia. Meanwhile in the second context, post-colonial marked a stream of philosophical, sociological, literary and cultural thinking. Even though it looked like it moved at a different level, both of them take the same starting point for analysis, namely the independence event until later times. (Mishra \& Hodge, 1993, p. 284) Assuming, there was complete discontinuation, marked by structured changes in all aspects of community life. A reversal of the structure of colonial consciousness.

In the framework of the post-colonial paradigm, various normative markers that accompanied the Proclamation event will be dissected. These markers became relevant, considering the Proclamation signified the transition of "Indonesia" from a category of imagined community to a category of the legalrational community (Azis, 2015, p. 59). The events of the Proclamation succeeded in ending the duality of legal and identity of the Dutch East Indies community, as well as alleviating subordination under the colonial system.

After the Proclamation, Indonesia had the authority to determine the format and direction of its own legal system. Through legitimacy based on these events, the newly formed government then formed a number of positive legal norms to run the country. One monumental one was the 1945 Constitution (UUD 1945).

What will be the focus of this paper discussion is the Preamble of the 1945 Constitution. Some experts assessed that the Preamble contained the legal ideals that form the basis for the formation of lower legislation (Kaelan, 2011, p. 521). The opening also included the aim of the Indonesian state, which is to "protect all the people of Indonesia and all the independence and the land that has been struggled for, and to improve public welfare, to educate the life of the people and to participate toward the establishment of a world order based on freedom, perpetual peace and social justice" (Indonesia, Constitution of 1945, Preamble). 
The Preamble of 1945 Constitutions as Post-Colonial Normative Expression and Its Contextuality (A Politics of Law Analysis)

The Manuscript for the Preamble of the 1945 Constitution was originally part of a document compiled separately from the 1945 Constitution, and popularly known as the Jakarta Charter. It was only at the session of ratification of the 1945 Constitution on August 18, 1945, the Jakarta Charter was ratified as an inseparable part of the 1945 Constitution. The Preamble of the 1945 Constitution had never changed since it was first adopted as positive law. Later, this paper attempted to show the various post-colonial paradigms in the Preamble to the 1945 Constitution.

\section{Theoretical Framework}

Political Law Studies often use various analysis tools and diverse perspectives, along with the range of the spectrum of political ideology. The choice of one analysis method will show the observer's alignment of the studied object. In this spectrum tension, where does the postcolonialism paradigm lie?

Before answering this question, the definition of "politics of law" has to be explained first. There are at least two notions of the term "politics of law". The first explanation is namely all official perspectives that provide direction for the process of forming legislation in Indonesia. In Indonesia, this definition is more relevant during the pre-reform period because it requires the existence of Garis-Garis Besar Haluan Negara (GBHN) as the main reference (Arinanto \& Fatmawati, 2017, p. 1). Since the Reformation and amendments to the constitution, the MPR lost its authority to form GBHN (Article 3 paragraph (1) of the 1945 Constitution).

In the second sense, politics of law is related to the influence of political configuration on the material character of a legal product. Law is assumed as a political product (Arinanto \& Fatmawati, 2017, p. 2). Mahfud MD describes the relationship between the two as relations between variables, where the political configuration is positioned as an independent variable and the character of the legal product is positioned as the affected variable. In a democratic political configuration, the result of legal products tends to have responsive and autonomous characteristics. On the other hand, in the configuration of authoritarian politics, the legal products produced tend to be orthodox and oppressive (Mahfud MD, 1999, p. 6-7).

At the level of the constitution, a reflection of political and legal relations is described by Wheare. A constitution represents discourse and compromise between interests that take place in society when the constitution is formed. The constitution also reflects the economic and social direction. The constitution, therefore, is the resultant of all these elements (Wheare, 2005, p. 107). In this context, postcolonialism can be integrated as a method of legal politics analysis. Postcolonialism offers a perspective that dissects the political situation after the independence of a nation.

The basic assumption is that the order born from this worldview is an anti-thesis of the ideological structure of colonialism. It, according to Ania Loomba, became a manifestation of resistance to colonial domination and inheritance. The context of post-colonial studies includes two overlapping aspects, including the history of the release of colonialism and ideological revolution, subjectivity, and culture (Wheare, 2005, p. 29-30). Two contexts of postcolonial studies were also revealed by Vijay Mishra and Bob Hodge. Postcolonialism can be seen either as an ideological orientation or as a historical act. Both of them may be intertwined, considering that postcolonial ideology is generally found in countries that have experienced independence (Mishra \& Hodge, 1993, p. 284). In the context of legal politics, postcolonialism portrays various anti-colonial elements in the post-independence legal products.

In the study of Legal Politics, there are several theses that seem to accommodate the postcolonialism paradigm in its analysis. This is as seen in the article entitled Africa's Constitutional Renaissance?, p. Stocktaking in the ' 90 s written by Clive Napier. Based on research on a number of nation-states in Africa that have experienced a period of colonialism, Napier formulated that the development of constitutionalism in Africa is at least through four stages (Napier, 2000, p. 80-84)

1. Pre-Colonial Arrangement. At this stage, Napier said there was no adequate record of constitutionalism in Africa. Recorded a number of immigrant communities in southern Africa already have their own constitution, but most indigenous tribes inhabiting the African continent do not have a political system organized by norms and values equal to the constitution.

2. Hegemony Colonial Settings. Colonial arrangements succeeded in organizing the indigenous life of Africa through hegemony. The implementation has a different model between one colonial region and another. Through the constitution as the highest product of public law, the relationship between the colonizer and the colonized is further defined.

3. Independence Period. Napier's view of the practice of constitutionalism during the independence period seemed cynical. During the period of independence, the constitution was 
designed limited by the political elite in the metropolis and was accepted by local elites. Very little input can be given by local participants in the constitution formulation process. As a result, the constitution that was passed did not reflect local needs. The constitutions in a number of newly born African countries only accommodate the personal interests of the elites and their parties.

4. Post-1990. This phase was marked by an effort to review the division of powers in the constitution, which led to reforms and amendments. Even though the amendments have been implemented several times after independence, the changes during the 90s brought a totally different spirit, namely democratization, and globalization.

The situation of the nations in Africa is very relevant to be compared with the one happens on Indonesian. Both have been oppressed under the rule of other nations and have lost their sovereignty to self-determination their fate. This similarity then led to the 1955 Asian-African Conference in Bandung. The foundation of this joint is international solidarity as a nation that was once colonized. Although at the time the conference was held, many Asian-African countries had won independence, but some other nations were still in the process of struggle for it ("Sejarah Konferensi Asia Afrika," n. d.).

In Napier's conceptualization, the main reflection of post-colonial studies is a measurable history. Each stage is a continuation of the previous chapter, but at the same time also decides the validity of the old elements. In the next section, while discussing post-colonialist expressions in the Preamble of the 1945 Constitution, the second and third stages in the construction of Napier will be presented as the main analytical framework.

\section{Results and Discussion}

\subsection{The Formulation Process}

As mentioned in the previous discussion, the development of constitutionalism in post-colonial countries is generally through four stages. These stages, as formulated by Clive Napier, consist of 1) pre-colonial arrangements, 2) arrangements for colonial hegemony, 3) independence period and 4) post-1990.

Analysis of legal politics after colonialism in the Preamble of the 1945 Constitution will then focus on the second, the third, and the fourth stages. The second stage is characterized by the existence of the invaders' hegemony over the colonized. The hegemony is then formalized through the arrangement of citizenship relations in the colonial constitution. While in the third stage, the constitution that is formed after independence often breaths elitist and fails to translate local needs. Hypothetically, the two stages are part of a dialectical process that produces a post-colonial mind in Indonesia. The latter is positioned as an anti-thesis of the formal colonialism structure in the form of the Dutch East Indies colony.

In accordance with the characteristics of Napier's colonial legal system, the constitution of the Dutch East Indies is hegemonic towards the lives of indigenous people. The hegemonic nature appears in minimal accommodation of indigenous interests in the constitution. In the Dutch constitution, which regulates the relationship between colonial land and the host country, colonies appear to be sidelined. It is formulated that "the territory of the Dutch kingdom consists of the Kingdom in Europe; its colonies and areas belong to it on several continents." This formula is solely aimed at affirming the inequality of rights between the inhabitants of the colony and the royal population in Europe (Paulus, 1979, p. 27).

During the period of colonialism, the people of Nusantara then had a new identity based on the differentiation of rights. The Archipelago is placed as a subordinate of the European nation that controls the superstructure. Discriminatory politics is also reflected in the product of colonial law which also has a discriminatory character. One of the examples is the citizenship law. Article 163 of the Indische Staatsregeling (IS) composes Dutch Indies citizenship in a hierarchical structure. Europeans occupied the highest place, then foreigners as second-class citizens, and Indigenous people at the lowest (Paulus, 1979, p. 74). Different categories of civil law apply to each class.

The colonial government and European nations were placed in a superior position in society. The indigenous position as The Other in their own land eventually become one of the triggers for the Indonesian national movement and struggle. This struggle, according to Kahin (2013, p. 51-54), is also catalyzed by at least five things, p. 1) similar perceptions of the geographical boundaries of Indonesian nationality. The boundary-brick is not merely formed based on the territory of the Dutch East Indies, but also refers to the boundaries of the two major kingdoms that have existed before the Dutch colonialization period, namely Sriwijaya and Majapahit; 2) homogeneous religiosity, where 90 percent of the Dutch East Indies embraces 
The Preamble of 1945 Constitutions as Post-Colonial Normative Expression and Its Contextuality (A Politics of Law Analysis)

Islam; 3) the development of Malay language market as a social language used in almost the entire Dutch East Indies. Malay market language function as the lingua franca; 4) the presence of the Volksraad (People's Council) institution as the highest representative assembly for the indigenous class; 5) development of telecommunication equipment such as radio and newspapers. Eventually, the struggle meets its stellar point in the Proclamation of Independence, August 17, 1945. The day after, the 1945 Constitution then passed as a national constitution.

Interestingly, the process of formulating the Preamble of the 1945 Constitution has been carried out for months before the Proclamation of August 17, 1945. Even then, it is difficult to be certain about the implementation of the basics of this state that contained/set in the Proclamation text. However, it is the ideals of a future sovereign Indonesian nation that binds the formators to stay in the same forum.

The opening of the 1945 Constitution is formulated by Committee 9 (2010, p. 18-19), an informal forum which is part of the Badan Penyelidik Usaha-Usaha Kemerdekaan (BPUPKI). BPUPKI, or Dokuritzu Zyundi Tyoosakai in Japanese, was formed on April 29, 1945, through the Gunseikan Commander (Japanese Army Commander) Number 23. (Tim Penyusun, 2010, p. 19) The formation of this body is a consequence of Japan's promises to hand over independence to Indonesia, due to a decline in performance in the war against allies. Formally, the promise is revealed by the Prime Minister of Japan on September 7, 1944.

The process of formulating the Preamble of the 1945 Constitution (2010, p. 23), which was first referred to as the Jakarta Charter, begun when the BPUPKI open a discussion on forming the supreme value of the country. Since May 29, 1945, the suggestions come from Muhammad Yamin, Soepomo, and Soekarno respectively. Each offers an interesting suggestion on the supreme value of the Indonesian state, and "force" the session leader to form a small forum to purify the idea. After June 1, Committee 9 begins to convene separately. Its membership consists of 5 representatives of Nationalist-Secular groups and 4 representatives of Nationalist-Religious, and Soekarno as the coordinator (2010, p. 12). On June 22, 1945, Soekarno for the first time announced the successfully formulated Jakarta Charter (p. 26).

This formulation is maintained until Indonesian independence on August 17, 1945. BPUPKI has agreed to place the Jakarta Charter as part of the Preamble of the constitution. However, the dynamics in the formulation of the Preamble apparently has not finished yet. In the seconds leading up to the ratification of the 1945 Constitution on August 18, 1945, Mohammad Hatta carries out a political maneuver to change the formulation of "Ketuhanan dengan kewajiban menjalankan syariat Islam bagi pemeluk-pemeluknya", in the fourth paragraph by approaching personally to Islamic leaders. Hatta has claimed that Christians in Eastern Indonesia has objected to that particular principle. If this formula is still passed, they threaten to secede from Indonesia (Latif, 2015, p. 83). Finally, the first principle formulation of the fourth paragraph is then changed into "Ketuhanan yang Maha Esa". This final formulation is then listed in the Preamble of the 1945 Constitution. ${ }^{1}$

1 The complete text of the Preamble of the 1945 Constitution:

"Bahwa sesungguhnya kemerdekaan itu ialah hak segala bangsa, dan oleh sebab itu maka penjajahan di atas dunia harus dihapuskan, karena tidak sesuai dengan perikemanusiaan dan peri-keadilan.

Dan perjuangan pergerakan kemerdekaan Indonesia telah sampailah kepada saat yang berbahagia, dengan selamat sentausa mengantarkan rakyat Indonesia ke depan pintu gerbang Negara Indonesia yang merdeka, bersatu, berdaulat, adil dan makmur.

Atas berkat rakhmat Allah Yang Maha Kuasa dan dengan didorongkan oleh keinginan luhur, supaya berkehidupan kebangsaan yang bebas, maka rakyat Indonesia menyatakan dengan ini kemerdekaannya.

Kemudian dari pada itu untuk membentuk suatu Pemerintah Negara Indonesia yang melindungi segenap bangsa Indonesia dan seluruh tumpah-darah Indonesia, dan untuk memajukan kesejahteraan umum, mencerdaskan kehidupan bangsa, dan ikut melaksanakan ketertiban dunia yang berdasarkan kemerdekaan, perdamaian abadi dan keadilan sosial, maka disusunlah kemerdekaan kebangsaan Indonesia itu dalam suatu Hukum Dasar Negara Indonesia yang terbentuk dalam suatu susunan Negara Republik Indonesia, yang berkedaulatan rakyat dengan berdasar kepada Ketuhanan yang Maha Esa, menurut dasar Kemanusiaan yang adil dan beradab, Persatuan Indonesia dan Kerakyatan yang dipimpin oleh hikmat kebijaksanaan dalam Permusyawaratan/Perwakilan, serta dengan mewujudkan suatu Keadilan sosial bagi seluruh rakyat Indonesia." 


\subsection{The Significance}

The Preamble of the 1945 Constitution and the 1945 Constitution are biological children of the Indonesian independence process. The proclamation itself allows the Indonesian people to establish their own legal system which is separated from colonial intimidation. The opening of the 1945 Constitution then inherits this spirit, in accordance with the character of postcolonialism, which, as described by Ania Loomba, bring a manifestation of resistance to colonial domination and inheritance. In the Preamble section of the 1945 Constitution, the post-colonial vibe is immediately visible in the first paragraph. The first paragraph asserts that " independence is the inalienable right of all nations, therefore, all colonialism must be abolished in this world as it is not in conformity with humanity and justice." The Indonesian nation is later built as an antithesis of these values.

As an affirmation, the call for independence is repeated in the second paragraph and is placed as a principle that is parallel to unity, sovereignty, justice, and prosperity. This independence is claimed to have been achieved through the process of struggle and movement. These claims are in harmony with the spirit of reversing the ideological structure of colonialism in post-colonial studies. Countries that are formed in post-colonial situations focus all their power and efforts on meeting the targets of modernization - through effective national reconstruction processes -, ideological, cultural, administrative, economic restoration, social norms, and educational structures (Kumar, 2005, p. 936).

The fourth paragraph of the Preamble has manifested the indicators that differentiating the structure of consciousness of the newly independent Indonesia with the colonial one. This paragraph contains the purpose of the state which is to " protect all the people of Indonesia and all the independence and the land that has been struggled for, and to improve public welfare, to educate the life of the people and to participate toward the establishment of a world order based on freedom, perpetual peace and social justice." There are several directions set by the founders of the nation, popularly known as Pancasila.

The choice of the Indonesian democratic principle contained in the fourth principle of Pancasila is an example of the opposition to the colonial paradigm set in the West mind. The fourth precept which reads "democratic life led by wisdom of thoughts in deliberation amongst representatives of the people " It appears there that the deliberation process is presented as a basic procedure for decision making. The Deliberation requires the existence of free negotiations involving all interested parties. Even unauthorized parties are indirectly involved as witnesses (Burns, 1999, p. 300). As Soepomo believes, this process is the antithesis of the concept of universal rights and social contracts between states and citizens as individuals per individual (Burns, 1999, p. 302).

However, is the constitutional formation process in Indonesia as elitist as Napier's accusations against post-colonial countries? The 1945 Constitution itself is formed by a Japanese-formed body called BPUPKI, whose membership was actually taken from elites close to Japan. Their position as elites is obtained from community approval, plus metaphysical abilities such as charisma (Seligman, 1989, p. 19). However, these indigenous elites are trying to explore the values in society as a basis for the constitutional material that they form. This was confirmed by Hilman Hadikusuma, who considered that adat was the soul of the legal system of an independent Indonesian republic.

\subsection{Contextualization}

Due to the end of the Cold War, various third world countries experience a wave of structural changes in the 1990s. Perhaps this is the reason Napier classified the 1990s as a separate period for post-colonial countries. In this decade, they undergo a reconfiguration process and led to the recontextualization of values that has been affirmed through legal instruments. Coincidentally, this wave of reforms also struck Indonesia, although it was not really caused by the end of the Cold War. The economic crisis in the late 1990 s then immediately followed by a political crisis to undermine the power of the New Order which has lasted for 32 years.

Reformation in 1998 is immediately followed by pressure to reform the constitution. The 1945 Constitution then experiences four stages of amendment that changed its structure and content radically. However, the political elite in the MPR decides to maintain a number of fundamental things, including the Preamble section which is decided not to be changed at all $(2010$, p. 4). Therefore, the Preamble position as the basic value for new articles in the constitution is not deterred and kept as relevant.

One of the greatest homework born from the Preamble is about embodying social justice. This notion of social justice is one of the main ideas of the Preamble, which conditions Indonesian human beings to have the same rights and obligations to eradicate injustice and inequality (Huda, 2017, p. xix). In fact, as a postcolonial state, Indonesia still has to deal with what Alavi calls "relative autonomy", as a continuation of the 
The Preamble of 1945 Constitutions as Post-Colonial Normative Expression and Its Contextuality (A Politics of Law Analysis)

weak development of social classes (Hadiz, 1999, p. 55). Although it has tried to escape the structural influence of colonialism, the post-colonial state still inherits the consequences of the failure of the colonial state to dominate the domestic class, so those classes do not grow proportionally (Hadiz, 1999, p. 58). Empirically, this is at least seen from the index of social inequality in Indonesia which is still very high. According to Infid's research, 84 percent of Indonesians perceive this inequality, especially related to income (Affan, 2018). Even so with the results of World Bank research, which states that Indonesia's economic growth in the past decade is actually only enjoyed by the richest 20 percent of the population (Khalika, 2018). Politically, this discourse of injustice fails to be mainstreamed and only to be repopularized again and again at the moment of the general election.

For this reason, the struggle for social justice must be affirmed in two dimensions at once. In the national dimension, Airlangga emphasizes the need to go beyond the "assumptions of the separation between social movements and the dynamics of political society." The struggle for social justice should not merely rely on the good intentions of the government but must be seen as a collaboration between social movements, institutions research, and democratic political power in parliament. At the level of civil society, the formation of rival discourses regarding injustice can be manifested. While at the political level, the movement can be involved in the process of formulating policies and legislation (Pribadi, 2009, p. 37). This is in line with the spirit of the Preamble which mandates the work of fulfilling social justice for all elements of the nation.

\section{Conclusions}

The study of legal politics in the perspective of postcolonialism emphasizes its study on the legal system of countries that have been under colonial rule, before declaring independence. The context of post-colonial studies includes two overlapping aspects, including the history of the release of colonialism and ideological revolution, subjectivity, and culture. Within the framework of the study of legal politics, post-colonialism portrays various anti-colonial elements in post-independence legal products.

The opening of the 1945 Constitution as the biological child of the independence event of August 17, 1945, contains normative elements of the postcolonial paradigm. In all its parts, it is often found that the affirmation of "independence" is the basis of the new Indonesian legal system. As the countries formed in the post-colonial situation, the Preamble of the 1945 Constitution provides the basis for meeting the targets of modernization - through an effective national reconstruction process -, ideological, cultural, administrative, economic, social norms and educational structures. The aim is solely to erase the influence of the colonial paradigm within an independent Indonesian state.

As part of the highest source of positive law in Indonesia, the legislators need to inspire the postcolonial values in the Preamble of the 1945 Constitution. The Preamble of the 1945 Constitution contains the ideas and crystallization of the struggle for Indonesian independence. The lawmakers need to interpret it as an inspiration in forming legislation that addresses the interests of the Indonesian people and does not succumb to the will of other nations. The opening of the 1945 Constitution of the Republic of Indonesia is still relevant as a platform to fulfill social justice for all Indonesian people.

\section{References}

1. Naskah Komprehensif Perubahan Undang-Undang Dasar Negara Republik Indonesia Tahun 1945. Latar Belakang, Proses, dan Hasil Pembahasan 1999-2002, Buku II Sendisendi/Fundamen Negara (Jakarta: Sekretariat Jenderal dan Kepaniteraan Mahkamah Konstitusi Republik Indonesia, 2010).

2. Affan, H. "Ketimpangan Sosial di Indonesia Meningkat,. Apakah Maknanya bagi Rakyat Biasa?" https://www.bbc.com/indonesia/indonesia-42989531.Accessed at 20 Agustus 2018.

3. Arinanto, S \& Fatmawati. (2017) "Silabus Perkuliahan Politik Hukum (2 SKS) Semester Genap, 2016-2017." Jakarta: Universitas Indonesia.

4. Azis, A.P A. (2015) "Kritik atas Prinsip Obyektivitas Berbasis Grundnorm dalam Teori Hierarki Norma: Studi Perbandingan Sejarah Hukum Tata Negara Indonesia dan Jerman". Bachelor Minor Thesis. University of Brawijaya. Malang. 
5. Burns, P. J. (1999) The Leiden Legacy: Concepts of Law in Indonesia. Jakarta: Pradnya Paramitha. 1999.

6. Hadiz, V. R. (1999) Politik Pembebasan: Teori-teori Negara Pascakolonial. Yogyakarta: Pustaka Pelajar \& Insist Press.

7. Hamidi, J. (2006) Revolusi Hukum Indonesia: Makna, Kedudukan dan Implikasi Hukum Naskah Proklamasi 17 Agustus 1945 dalam Sistem Ketatanegaraan RI. Jakarta: Konstitusi Press.

8. Huda, N. (2017) "Kata Pengantar." In Susanto Polamolo. Kekuatan Hukum Preambule UUD 1945: Menembus Selubung Nomologis dan Membongkar Struktur Dasar Konstitusi. Yogyakarta: Ifada Publishing. 2017.

9. Indonesia. Constitution of 1945.

10. Kaelan. (2011) Negara Kebangsaan Pancasila: Kultural, Historis, Filosofis, Yuridis dan Aktualisasinya.Yogyakarta: Paradigma.

11. Kahin, G. McTurnan. (1959) Nationalism and Revolution in Indonesia. New York: Cornell University Press.

12. Khalika, N.N. “Lingkaran Setan Ketimpangan Sosial di Indonesia.” https: //tirto.id/lingkaran-setanketimpangan-sosial-di-indonesia-cFhB.Accessed at 20 September 2018.

13. Kumar, B. (2005) "Postcolonial State: An Overview". The Indian Journal of Political Science. Vol. 66.No. 4. (Oct.-Dec. 2005), p. 936.

14. Latif, Y. (2015) Negara Paripurna: Historisitas, Rasionalitas, dan Aktualitas Pancasila. Jakarta: Gramedia Pustaka Utama.

15. Loomba, Ania. (2016) Kolonialisme/Pascakolonialisme [Colonialism/Postcolonialism]. Diterjemahkan oleh Hartono Hadikusumo. Yogyakarta: Narasi dan Pustaka Promathea..

16. Mahfud MD, M. (1999) Pergulatan Politik dan Hukum di Indonesia. Yogyakarta: Gama Media.

17. Mishra, V \& Hodge, B. (1993) What is Post (-) colonialism? in William, P \& Chrisman, L. Eds. Colonial Discourse and Post-Colonial Theory, $p$. A Reader. Hertfordshire, p. Simon \& Schuster International Group p. 284

18. Museum Konperensi Asia Afrika, "Sejarah Konferensi Asia Afrika", http://asianafrican museum.org/sejarah-konferensi-asia-afrika/. Accessed at 5 September 2018.

19. Napier, C. (2000) “Africa's Constitutional Renaissance?: Stocktaking in the '90s" Africa Dialogue Monograph Series. Vol. 1.No. 1. (January 2000): 80-84.

20. Paulus, BP. (1979) Garis Besar Hukum Tata Negara Hindia Belanda. Bandung: Alumni.

21. Pribadi, A. (2009) "Keadilan Sosial di Era Globalisasi: Politik Transformatif Gerakan Sosial berbasis Keadilan Redistribusi dan Rekognitif." In M Faishal Aminuddin (Ed). Globalisasi dan Neoliberalisme: Pengaruh dan Dampaknya bagi Demokratisasi Indonesia. Yogyakarta: Logung Pustaka.

22. Seligman, Lester. G. (1989) Perekrutan Kaum Elit dan Pembangunan Politik (Elite Recruitment and Political Development) Translated by Aidit Alwi and Zainal. in Aidit Alwi and Zainal, Eds. Elit dan Modernisasi. Yogyakarta: Liberty. p. 19

23. Tim Penyusun. Naskah Komprehensif Perubahan Undang-Undang Dasar Negara Republik Indonesia Tahun 1945: Latar Belakang, Proses, dan Hasil Pembahasan 1999-2002, Buku I Latar Belakang, Proses, dan Hasil Pembahasan UUD 1945 (Jakarta: Sekretariat Jenderal dan Kepaniteraan Mahkamah Konstitusi Republik Indonesia, 2010). p. 19

24. Wheare, K. C. (2005) Konstitusi-Konstitusi Modern [Modern Constitution] (M. Hardani, trans). Surabaya: Pustaka Eureka. 